\title{
Examining derelict pot impacts on harvest in a commercial blue crab Callinectes sapidus fishery
}

James A. DelBene

Virginia Institute of Marine Science, jadelbene@vims.edu

Donna M. Bilkovic

Virginia Institute of Marine Science, donnab@vims.edu

Andrew M. Scheld

Virginia Institute of Marine Science, scheld@vims.edu

Follow this and additional works at: https://scholarworks.wm.edu/vimsarticles

Part of the Aquaculture and Fisheries Commons

\section{Recommended Citation}

DelBene, James A.; Bilkovic, Donna M.; and Scheld, Andrew M., "Examining derelict pot impacts on harvest in a commercial blue crab Callinectes sapidus fishery" (2019). VIMS Articles. 1349.

https://scholarworks.wm.edu/vimsarticles/1349 
Title: Examining derelict pot impacts on harvest in a commercial blue crab Callinectes sapidus fishery

James A. DelBene ${ }^{*}$, Donna M. Bilkovic ${ }^{1}$, Andrew M. Scheld ${ }^{1}$

${ }^{1}$ Virginia Institute of Marine Science, William \& Mary, P.O. Box 1346, Gloucester Point, VA 23062

*Corresponding author

Email: jadelbene@vims.edu

Declarations of interest: none

Contributors:

James A. DelBene - developing study design, conducting field work, data analysis, writing original draft, writing - review and editing

Donna M. Bilkovic - developing study design, data analysis, writing - review and editing

Andrew M. Scheld - developing study design, data analysis, writing - review and editing 


\begin{abstract}
Keywords: Blue crab, derelict fishing gear, Chesapeake Bay, commercial fishery, marine debris

Pot fisheries occur worldwide with a significant proportion of the gear becoming derelict. Derelict pots induce detrimental ecological and economic impacts, and more recently were found to reduce blue crab harvests in the Chesapeake Bay commercial fishery. We simulated the presence of derelict pots near actively fished pots in seasonal field experiments to quantify the effect derelict pots have on blue crab harvest. Derelict pots reduced harvests by 30\% during the summer, but not during the fall. Female blue crab capture rates were consistently lower when derelict pots were present; while capture rates of the less abundant males were not negatively affected by derelict pots. Variable responses to derelict pots may be due to seasonal differences in female and male blue crab behavior and movements. The costly effect that derelict pots have on harvest should be investigated in other pot fisheries to recognize the magnitude and mechanisms behind these impacts.
\end{abstract}

\title{
Highlights:
}

- Derelict blue crab pots can reduce harvests in actively fished pots

- The effect of derelict pots on harvest differs seasonally

- Reduced harvests due to derelict pots were more evident in female blue crabs 


\section{Introduction}

Derelict fishing gear (DFG) is a type of marine debris that consists of any fishing gear that is lost, abandoned, or otherwise discarded, such as nets, pots, trawls, and longlines (Macfadyen et al. 2009, Bilkovic et al. 2016). Several factors contribute to the presence of DFG, such as: operational fishing activities; intentional abandonment; gear conflicts; vessel-gear interactions; vandalism and theft; faulty, degraded, or failed equipment; and storms and weather (Macfadyen et al. 2009, FAO 2010, Bilkovic et al. 2016, Gilman et al. 2016). A steady increase in fishing effort and improvements in the lifespan of synthetic materials have led to an increase in abundance and persistence of DFG in the marine environment (Macfadyen et al. 2009).

Derelict pots are a prevalent form of DFG that occur globally and are responsible for significant ecological and economic impacts (Guillory 1993, Macfadyen et al. 2009, Arthur et al. 2014, Bilkovic et al. 2016, Scheld et al. 2016, Wilcox et al. 2016). Continued self-baiting contributes to "ghost fishing" by derelict pots that indiscriminately capture target and non-target animals including finfishes, water birds, turtles, mammals, and other invertebrate species (Guillory 1993, Havens et al. 2011, Arthur et al. 2014). These animals may become injured, drown, or be consumed by other organisms in the pots (Guillory 1993, Matsuoka et al. 2005). Bycatch mortalities by derelict pots frequently remove individuals that would otherwise contribute to valuable recreational and commercial fisheries (Guillory 1993, Bilkovic et al. 2014). Derelict pots may also degrade sensitive habitats (e.g., seagrasses, marshes) by smothering plants, abrading or removing blades of grass, and through scouring areas (Uhrin et al. 2005, Uhrin and Schellinger 2011, Arthur et al. 2014). Additionally, derelict pots can be a navigation hazard for boaters and can cause costly damage to boat propellers and engines if the buoy line wraps around the propeller (Matsuoka et al. 2005). Attraction towards derelict pots and 
away from actively fished pots can reduce harvests of target species in a pot fishery, whether or not the target species enter derelict pots (Fig. 1; Scheld et al. 2016).

In 2015, the US commercial blue crab Callinectes sapidus fishery landed over 73 thousand metric tons of blue crab valued at US \$220 million (NMFS 2017). The blue crab is a shellfish of significant ecological (Van Engel 1958, Virnstein 1977, Hines et al. 1990) and economic importance on the Atlantic seaboard and Gulf Coast of the United States (Kennedy et al. 2007, NMFS 2017). Commercial and recreational blue crab fisheries primarily utilize pots, typically 0.6 x 0.6 x $0.6 \mathrm{~m}$ rigid wire mesh cubes with an upper and lower chamber (Kennedy et al. 2007). Blue crab pots can continue to fish for two or more years after becoming derelict (Matsuoka et al. 2005, Havens et al. 2008). Blue crab fisheries largely operate in inshore or nearshore environments, leading to a high likelihood of vessel-gear interactions that contribute to increased numbers of derelict pots. Impacts of derelict pots, such as reducing stocks of target and nontarget species, decreasing fishery profits, and contributing to user group conflicts, have been well documented in US blue crab fisheries (Guillory et al. 2001, Anderson and Alford 2014, Bilkovic et al. 2016, Scheld et al. 2016).

The Chesapeake Bay is the largest estuary in the US and is responsible for $30-40 \%$ of US blue crab commercial harvests valued at over US $\$ 85$ million in 2015 (NMFS 2017). Crab pots are the predominant gear used to harvest blue crabs in both the hard and soft crab fisheries. Following the 2008 US Department of Commerce's declaration of a federal fishery failure in the Chesapeake Bay blue crab fishery, the Virginia Marine Debris Location and Removal Program (2008-2012) was developed and implemented to locate and remove DFG. The program collected data on the abundance and distribution of derelict pots in the Chesapeake Bay (Bilkovic et al. 2014). Subsequent data analyses found that $12-20 \%$ of all pots licensed throughout the 
Chesapeake Bay each year become derelict (approximately 145,000 derelict pots are predicted to be present at any given time; Bilkovic et al. 2016). This high prevalence of derelict pots may intensify negative impacts, affecting fishery resources and the well-being of commercial fishers and local communities who rely on the Chesapeake Bay.

Several past studies have identified the direct loss of biomass in the population of target species (e.g., blue crab, Dungeness crab Cancer magister) due to ghost fishing mortalities by derelict pots over time (Breen 1987, Guillory 1993, Havens et al. 2008, Giordano et al. 2010, Antonelis et al. 2011, Anderson and Alford 2014, Bilkovic et al. 2014, Voss et al. 2015). For example, bycatch mortality of blue crabs in derelict pots is estimated at 20-26 crabs per pot per year (Guillory 1993, Giordano et al. 2010, Bilkovic et al. 2016). However, limited research has focused on the instantaneous effect on harvest resulting from competition between derelict and actively fished pots. Recent analysis evaluating the Virginia Marine Debris Location and Removal Program and a smaller targeted removal effort the following two winters (2012-2013 and 2013-2014) in Virginia found removal of 34,408 derelict pots increased harvest by 30 million pounds over the course of the programs (Scheld et al. 2016). Derelict pots may compete with nearby actively fished pots by attracting blue crabs away from pots that fishers actively harvest and bait, whether for structure, shelter (Everett and Ruiz 1993), or foraging for food. Reduction in pot efficiency forces fishers to invest more time, money, and resources to harvest blue crabs in the presence of derelict pots, reducing fishery profits (Scheld et al. 2016). The large-scale analysis of Scheld et al. (2016) used established statistical methods to identify treatment effects in fishery harvests and derelict pot removal data, and suggested a novel economic impact caused by derelict pots. However, data on derelict pot removals was not collected for this purpose and further research is needed to experimentally test the effect that 
derelict pots have on harvest. The objectives of this study were to (1) experimentally evaluate the effect that derelict pots have on blue crab harvest in actively fished pots, which we hypothesize to be negative, and (2) investigate environmental and temporal factors influencing possible interaction between derelict and actively fished pots.

\section{Materials and methods}

\subsection{Study site}

The study site was in the Mobjack Bay, Virginia, in lower Chesapeake Bay (37²0’60.0” N, 76¹9’57.9” W), a microtidal estuary with a tidal range of approximately $1 \mathrm{~m}$. This site is polyhaline with soft sediment substrate and less than $2 \mathrm{~m}$ water depth. Submerged aquatic vegetation (SAV) is adjacent to the entire site and the shoreline is characterized by low-density residential development. Fishers regularly crab in this area throughout the Virginia commercial blue crab season (March - November).

\subsection{Experimental design}

A control group of ten actively fished crab pots without derelict pots nearby and a treatment group of ten actively fished crab pots with two derelict pots approximately 15 to $20 \mathrm{~m}$ away from each active pot (one on either side) were deployed with help from a commercially-licensed fisher (Fig. 2). The active pots were constructed by the commercial fisher from galvanized wire, and the derelict pots were minimally used, vinyl coated wire that we originally purchased as new. Actively fished pots were regularly baited, whereas derelict pots were unbaited. Blue crabs use chemosensory cues to detect prey up to 15 m away (Hines et al. 2009). As our study was focused on gear competition between active and derelict pots, we placed derelict pots in the treatment group outside of the active pot detection radius. This reduced the likelihood that blue crabs initially attracted to the unbaited, derelict pots would divert to the active pots for bait (see Fig. 1). 
The control (active pots only) and treatment (active pots and two derelict pots) groups were approximately the same distance from shore and placed in similar habitats to maintain consistency across the groups throughout the study. The groups were separated by roughly 260 $\mathrm{m}$ to ensure independence. Blue crabs are mobile; therefore, independence of experimental groups was determined by separating the two groups beyond the blue crab prey detection distance of $15 \mathrm{~m}$ (Hines et al. 2009) and further than the typical distance crabbers place between pots in the Chesapeake Bay (approx. $40 \mathrm{~m}$ ). Within the control and treatment groups, active pots were separated by approximately $40 \mathrm{~m}$, following typical pot deployment patterns used by crabbers in Chesapeake Bay. Pots in the control and treatment groups remained in the same physical location throughout the experiment to reduce confounding site and treatment effects, because site effects could change over time due to the extensive daily movements and seasonal migration of blue crabs.

A Humminbird ${ }^{\mathrm{TM}}$ Side Scan unit was used to identify and mark with a GPS point any unknown derelict pots in the sampling area before and after each sampling period (as per Havens et al. 2011). Furthermore, for the duration of the study any actively fished pots observed within $20 \mathrm{~m}$ of experimental pots were noted to account for additional pots that may compete with experimental pots.

\subsection{Data collection and summary}

Blue crab harvest and bycatch data were collected from each actively fished pot in the control and treatment groups for 11 days during each of the two sampling periods in 2017 (summer: August 9-24; fall: October 11-November 4). Actively fished pots were sampled within three days after deployment and all catch were removed and recorded. Following standard commercial crabbing practice, all legal-size crabs were harvested, and sublegal-size crabs were 
released. The 22 sampling days resulted in 22 replicates and 110 subsamples of data collected from the ten active pots in each experimental group (control, treatment). In addition, ancillary data were collected on each sampling day from one of the 20 derelict pots in the treatment group. The derelict pot was randomly selected using a random number generator and subsequently checked (i.e., any animals present were noted, and pots were redeployed with animals still in pot). We limited the number of times derelict pots in the treatment group were checked to more closely simulate derelict pots that would not be exposed to these disturbances. Additional derelict pots were occasionally checked for logistical reasons, such as repositioning of pots. All derelict pots in the treatment group were sampled on the final sampling day of each season. Crab carapace width (legal: $\geq 127 \mathrm{~mm}$; sublegal: $<127 \mathrm{~mm}$ ), sex (male, female), and bycatch species and abundance were recorded for each pot sampled. Sampling days were not always consecutive throughout the seasons due to foul weather, vessel maintenance, scheduling conflicts, and closure of the Virginia commercial blue crab fishery on Sundays. Between seasons, all active pots were removed from the study site while derelict pots were disarmed and remained in the water at the study site.

We noted daily water temperatures as well as the time each pot was checked to enable calculation of soak time (i.e., the duration of time each pot was in the water before being sampled). Daily salinity measurements were collected from NOAA's York Spit Chesapeake Bay Interpretive Buoy System buoy. These measurements closely align with those at nearby Mobjack Bay. Submerged aquatic vegetation cover during 2017 near the sample site was obtained from the VIMS SAV Program that annually maps SAV distribution in Chesapeake Bay from multispectral digital imagery (http://web.vims.edu/bio/sav/). Water temperature, salinity, and 
SAV cover were plotted and mapped to examine as possible environmental factors that may influence crab catch.

\subsection{Data analyses}

For each sampling event, capture rates (crabs/pot/day) were calculated for individual active pots in the control and treatment groups by dividing the count data (e.g., number of legal-size blue crabs) by the number of days the pot was in the water. Median and mean capture rates for legal-size, sublegal-size, and total catch were viewed across and within seasons to detect any catch differences between active pots in the control and treatment groups. Active pot capture rates were then analyzed by sex for legal-size, sublegal-size, and total catch within each experimental group after being separated by season. Shapiro-Wilk tests were used to test for normality in the capture rates and Mann-Whitney U tests were used to compare non-normal capture rates between the active pots in the control and treatment groups of each season. As a robustness check, additional Mann-Whitney U tests were used to compare legal-size capture rates between experimental groups considering: 1) individual pot as a replicate for experimental groups with sampling days as subsamples, and 2) sampling day as a replicate for each experimental group with individual pots as subsamples. In addition, bycatch was recorded during sampling events of all pots (active and derelict) in the control and treatment groups. Bycatch capture rates (individuals/pot/day) of blue crab or other species were calculated and compared across seasons (Mann-Whitney U test).

A negative binomial generalized linear mixed model (GLMM) was used to investigate the effect of derelict pot presence $($ control $=$ no derelict pots present, treatment $=$ two derelict pots present), season (summer, fall), and soak time (1, 2, or 3 days) on the number of legal-size blue crabs harvested per active pot. Variation in conditions across pot locations (e.g., position in the 
line of pots, nearby habitat) was accounted for by including an individual pot identifier as a random effect. The same model structure was used to evaluate effects on total (legal and sublegal-size) blue crabs captured per pot. To account for variation in sampling days (e.g., due to changes in the local environment), a second version of the GLMM was developed including sampling day as a random effect instead of individual pot. The use of individual pot and sampling day as random effects in separate GLMMs ensured results were robust to possible site effects across pot locations and changes in local environmental conditions across days (e.g., changes in water temperature and salinity), respectively. All statistical work was performed in R (R Core Team 2018) and the glmer.nb function in the lme4 package was used to estimate GLMMs (Bates et al. 2015). The function bootMer, also contained in the lme4 package, was used to perform a parametric bootstrap where the model was re-estimated 1,000 times (Bates et al. 2015). Bootstrap estimates were used to calculate means, standard errors, and the significance for GLMM parameters and predictions.

\section{Results}

No preexisting or newly introduced derelict pots were identified using side-scan sonar within the study site and no additional actively fished pots were observed within $20 \mathrm{~m}$ of the experimental pots. Throughout this study, the capture rate of legal-size blue crabs was similar across the two seasons (summer: mean $\pm \mathrm{SE}=4.13 \pm 0.17 \mathrm{crabs} /$ pot/day; fall: mean $\pm \mathrm{SE}=4.49$ \pm 0.18 crabs/pot/day; Fig. 3). During the summer, active pots in the control group captured significantly more legal-size and total blue crabs per pot per day than the treatment group; however, during the fall there was no significant difference between active pot capture rates in the control and treatment groups (Table 1). Results from the additional Mann-Whitney U tests were similar to Table 1 and robust in treating individual active pot samples and sampling days as 
independent observations. Additionally, the capture rates of total blue crabs in derelict pots were similar between the two seasons $(U=411, p>0.05)$ and the bycatch capture rate of other species in derelict pots was relatively low (summer: mean $\pm \mathrm{SE}=0.04 \pm 0.01$ individuals/pot/day; fall: mean $\pm \mathrm{SE}=0.24 \pm 0.07$ individuals/pot/day). Bycatch species consisted predominantly of spider crab Libinia emarginata $(\mathrm{n}=19)$, black sea bass Centropristis striata $(\mathrm{n}=6)$, and sheepshead Archosargus probatocephalus $(\mathrm{n}=5)$ in the derelict pots, whereas northern puffer Sphoeroides maculatus $(\mathrm{n}=10)$, Atlantic spadefish Chaetodipterus faber $(\mathrm{n}=7)$, and spider crab Libinia emarginata $(\mathrm{n}=3)$ dominated the bycatch in the control and treatment group active pots. There was no significant difference in the capture rate of total bycatch between the control and treatment active pots $(\mathrm{U}=23,537, \mathrm{p}>0.05)$.

Most of the blue crabs captured throughout the experiment were females (76\%). During both seasons, the capture rates for total females were significantly greater in the control group than the treatment group (Table 2). Summer capture rates for legal-size females were significantly greater in the control group, but there was no significant difference in sublegal-size female capture rates. Conversely, in the fall legal-size female capture rates were similar between the active pots in the control and treatment groups, though capture rates for sublegal-size females were significantly greater in the control group. For the less abundant males, patterns of capture rates between the control and treatment varied from the females and by season. During the summer, capture rates for male blue crabs (legal-size, sublegal-size, and total) were similar between the control and treatment, while during the fall, capture rates for males (legal-size, sublegal-size, and total) in the treatment group were significantly higher than the control group. Overall, the absolute differences in average capture rates between control and treatment groups for females were always greater than those for males. 
During sampling events, the highest water temperature was $27.9^{\circ} \mathrm{C}$ and the lowest was 16.2 ${ }^{\circ} \mathrm{C}$. The water temperature was lower during the fall (summer: mean $=26.3^{\circ} \mathrm{C}$; fall: mean $=19.3$ $\left.{ }^{\circ} \mathrm{C}\right)$. Throughout the seasons, the salinity measured at the study site ranged from 19.9 to 23.4 PSU. Mean salinity in the summer was 20.4 PSU, and in the fall was 22.3 PSU. SAV cover was adjacent to and a similar distance from the control and treatment groups in our study site (min. 105 m, max. $171 \mathrm{~m})$.

Results from the negative binomial GLMM indicated that season, treatment, and an interaction between season and treatment had significant effects on the mean harvest in active pots. Model predictions of mean harvest for the summer were 5.96 ( $\mathrm{SE}=0.41$ ) crabs per pot per day and $3.92(\mathrm{SE}=0.30)$ crabs per pot per day for active pots in the control and treatment group, respectively. During the fall, control and treatment group model predictions of mean harvest were $4.68(\mathrm{SE}=0.34)$ crabs per pot per day and $4.54(\mathrm{SE}=0.34$; mean effects derived from bootstrap resampling model output, Table 3). Soak time did not significantly affect mean harvest (Table 3), likely because there was little variation in this variable (82\% of observations had a soak time of 1 day). Similar results were observed when the same model was used to estimate total catch of blue crabs and when the model was run with sampling day as the random effect.

\section{Discussion and conclusions}

The results from this study supported our hypothesis that the presence of derelict pots negatively impacts blue crab harvest. A significant harvest reduction (approx. two legal-size crabs per pot per day) was noted when derelict pots were present during summer but not fall. However, when considering capture rates by sex and focusing on females, the dominant sex

observed, female capture rates were largely lower when derelict pots were present in both seasons. This suggests that derelict pots were attracting blue crabs away from the nearby actively 
fished pots. Thus, blue crabs did not have to enter the derelict pot but may have been simply attracted to it and away from the active pots, resulting in reduced harvest. This is supported by the consistently low capture rates of derelict pots. For instance, during the summer only 0.26 (SE $=0.07)$ legal-size blue crabs per pot per day were observed in the derelict pots, which did not account for the magnitude of legal-size blue crab loss in the active pots of the treatment group (Table 1).

Variability in the "derelict pot effect" may be a result of the seasonal differences in blue crab behavior and movement in Chesapeake Bay (Van Engel 1958). For instance, the frequency of blue crab molting is reduced at lower water temperatures (Churchill 1919, Van Engel 1958). During molting, blue crabs seek structured habitats for refuge from predation (Hines 2007). A potential reduction in molting frequency during colder water temperatures of the fall could have resulted in less movement to seek refuge and fewer interactions with the derelict pots. Another possibility for differences observed between seasons could have been due to increased movement of blue crabs during the mating season that occurs from early May and into October, with a peak in late August and early September (Van Engel 1958). Blue crab mating movements to find a suitable mate would be limited during the fall sampling period (October 11-November 4) and could reduce the chance of interactions with derelict pots.

The reduced harvest effect of derelict pot presence was especially noticeable in the harvest of female blue crabs, which was consistently higher in control group active pots across both seasons. We expected to capture more females than males at the study site due to female preference for higher salinities (Van Engel 1958), but the decrease in harvest observed in active pots when derelict pots were present would imply that females are more likely than males to be attracted towards derelict pots and thus not enter nearby active pots. Such behavioral difference 
between sexes could explain the smaller impact of derelict pot removals that Bilkovic et al. (2016) observed in Maryland, where blue crab harvests are dominated by males as opposed to Virginia, where blue crab harvests are dominated by females (Miller et al. 2011). One possible reason for this disparity between sexes in our findings is differences in overwintering migration movements. Females migrate to the mouth of the Chesapeake Bay in late summer and early fall to spawn, whereas males remain in the brackish waters year-round (Churchill 1919, Van Engel 1958). This migration of females throughout the duration of our study would increase the possibility of female interactions with derelict pots, whereas males do not participate in such large-scale movements.

The complex movement of blue crabs within dynamic estuarine environments makes it difficult to account for all variation that occurs in harvests. As a dominant species in the Chesapeake Bay ecosystem, the blue crab utilizes multiple habitats throughout its life cycle (Churchill 1919, Van Engel 1958). Adults spend most time in soft-sediment environments, but have been observed in structured habitats, such as SAV and woody debris, foraging or seeking refuge (Wolcott and Hines 1990, Everett and Ruiz 1993, Bromilow and Lipcius 2017). Additionally, the patchiness and fine scale variability in habitats (e.g., SAV, oyster reefs, softsediment) and environmental parameters (e.g., salinity, temperature, dissolved oxygen, $\mathrm{pH}$ ) in the Chesapeake Bay influence the movement of blue crabs (Micheli and Peterson 1999, Stover et al. 2013, Cunningham and Darnell 2015, Glaspie et al. 2017). We attempted to control for this variation by focusing on a localized area during the late summer and mid to late fall that was positioned nearshore ( $<2 \mathrm{~m}$ depth), outside of SAV habitat, and on soft-sediment. In addition, there were 11 replicates for each pot location during each season and a GLMM was used to control for possible site- and time-specific influences when estimating treatment effects. 
Nonetheless, the effect of derelict pots was found to be variable throughout the year and by sex, possibly due to blue crab molting, mating, and migration patterns.

Derelict pots used in this study were never baited. This was a conservative representation of a derelict pot, as pots are regularly baited by commercial fishers and may become derelict afterwards. The occurrence of self-baiting in derelict pots has been shown to double their catch rate (Havens et al. 2008), which leads to an increased mortality of bycatch. Because derelict pots were not baited like the actively fished pots, blue crab detection distance and pot attractiveness would differ between derelict and active pots. Blue crabs are voracious opportunistic feeders, mostly consuming fishes, benthic invertebrates (including cannibalism), and plant matter (Williams 1974, Seitz et al. 2011). Fish such as Atlantic menhaden Brevoortia tyrannus are often used to bait blue crab pots due to their oily flesh. Blue crabs can use chemosensory cues to detect prey up to $15 \mathrm{~m}$ away (Hines et al. 2009), which would suggest a $15 \mathrm{~m}$ radius of attraction encircles each baited pot. The detection perimeter of a baited pot is important to consider, especially with the competition effect between derelict and active pots. Further investigation into the effect of distance on the interaction between derelict and active pots would improve our understanding of pot competition and the relationship between derelict gear and reductions in harvest.

Reductions in harvest due to the presence of derelict pots could be addressed by fishery managers to improve the efficiency of the fishery and increase profits. According to the most recent assessment in 2018, the Chesapeake Bay blue crab stock is not depleted, and overfishing is not occurring (Chesapeake Bay Stock Assessment Committee 2018). Furthermore, the exploitation fraction for female crabs was $21 \%$, which was less than the target of $25.5 \%$ and threshold of 34\% (Chesapeake Bay Stock Assessment Committee 2018). Lessening the impact of 
derelict pots on active fishery harvests would reduce the amount of time and money that commercial fishers spend to reach the current daily harvest limits, making fishing operations more profitable. Managers should consider the costs and benefits of mitigating harvest impacts and economic inefficiencies during comprehensive assessments of strategies addressing the issue of derelict pots.

The commercial blue crab fishery is one of many economically important pot fisheries (e.g., Dungeness crab, American lobster Homarus americanus, king crab Paralithodes camtschaticus, stone crab Menippe mercenaria) that support coastal communities. Our results suggest derelict pots are an uncontrolled inefficiency in the Chesapeake Bay blue crab commercial fishery; however, similar impacts in other pot fisheries have not been investigated. Efforts to mitigate impacts of derelict pots include removal programs, boater education, marine spatial planning, biodegradable escape panels, bycatch reduction devices, individual pot identification tags, and escape vents (Guillory 1993, Bilkovic et al. 2016). The potential effects of derelict pots on harvest observed in our study are primarily mitigated by removing or preventing the occurrence of derelict pots. However, derelict pot removal programs are expensive and require coordination among multiple parties to locate, remove, and then dispose of pots, whereas preventive actions (e.g., boater education to avoid pot buoys and lines, individual pot identification tags, spatial gear restrictions) can be less capital intensive though more politically challenging. Reduced harvests caused by derelict pots can be addressed through management actions and should be investigated in other pot fisheries. Globally, pot fisheries lose millions of pots each year (Macfadyen et al. 2009) that have the potential to significantly reduce harvests and increase the cost of fishing worldwide. Future studies should examine the prevalence of derelict pot impacts 
on harvests in other fisheries to better understand the magnitude of potential economic losses caused by derelict pots.

\section{Acknowledgements}

Funding for data collection during this project was provided by Virginia Sea Grant [grant number R71851K-PD]. These data would not have been possible without the invaluable field assistance from Dan Knott. This project benefited from the advice, support, and edits of Dr. Kirk Havens and Dr. Jeff Shields. Additionally, Maxine MacLeod provided the illustration (Fig. 1) to visualize the “derelict pot effect” and Dr. Robert Isdell helped design the study site map (Fig. 2). This paper is Contribution No. 3797 of the Virginia Institute of Marine Science, William \& Mary.

\section{References}

Anderson, J.A. and A.B. Alford. 2014. Ghost fishing activity in derelict blue crab traps in Louisiana. Marine Pollution Bulletin 79: 261-267.

Antonelis, K., D. Huppert, D. Velasquez, and J. June. 2011. Dungeness crab mortality due to lost traps and a cost-benefit analysis of trap removal in Washington state waters of the Salish Sea. North American Journal of Fisheries Management 31(5): 880-893. DOI: 10.1080/02755947.2011.590113

Arthur, C., A. Sutton-Grier, P. Murphy, and H. Bamford. 2014. Out of sight but not out of mind: Harmful effects of derelict traps in selected U.S. coastal waters. Marine Pollution Bulletin 86: 19-18.

Bates, D., M. Maechler, B. Bolker, and S. Walker. 2015. Fitting Linear Mixed-Effects Models Using lme4. Journal of Statistical Software 67(1): 1-48. DOI: 10.18637/jss.v067.i01

Bilkovic, D.M., K. Havens, D. Stanhope, and K. Angstadt. 2014. Derelict fishing gear in Chesapeake Bay, Virginia: Spatial patterns and implications for marine fauna. Marine Pollution Bulletin 80: 114-123.

Bilkovic, D.M., H.W. Slacum Jr, K.J. Havens, D. Zaveta, C.F. Jeffrey, A.M. Scheld, D. Stanhope, K. Angstadt, and J.D. Evans. 2016. Ecological and economic effects of derelict 
fishing gear in the Chesapeake Bay: 2015/2016 Final Assessment Report. Prepared for Marine Debris Program, Office of Response and Restoration, National Oceanic and Atmospheric Administration.

Breen, P.A. 1987. Mortality of Dungeness crabs caused by lost traps in the Fraser River Estuary, British Columbia. North American Journal of Fisheries Management 7: 429435. DOI: 10.1577/1548-8659(1987)7<429:MODCCB>2.0.CO;2

Bromilow, A.M. and R.N. Lipcius. 2017. Mechanisms governing ontogenetic habitat shifts: role of trade-offs, predation, and cannibalism for the blue crab. Marine Ecology Progress Series 584: 145-159.

Chesapeake Bay Stock Assessment Committee 2018. 2018 Chesapeake Bay Blue Crab Advisory Report. (Chesapeake Bay Program, 2018).

Churchill Jr, E.P. 1919. Life history of the blue crab. Bulletin of the Bureau of Fisheries 36: 95-128.

Cunningham, S.R. and M.Z. Darnell. 2015. Temperature-dependent growth and molting in early juvenile blue crabs Callinectes sapidus. Journal of Shellfish Research 34(2): 505-510.

Everett, R.A. and G.M. Ruiz. 1993. Coarse woody debris as a refuge from predation in aquatic communities: An experimental test. Oecologia 93: 475-486.

Food and Agriculture Organization of the United Nations (FAO). 2010. The State of World Fisheries and Aquaculture 2010. Rome: Food and Agriculture Organization of the United Nations. Available: http://www.fao.org/docrep/013/i1820e/i1820e00.htm. (January 2018).

Gilman, E., F. Chopin, P. Suuronen, and B. Kuemlangan. 2016. Abandoned, lost or otherwise discarded gillnets and trammel nets: methods to estimate ghost fishing mortality, and the status of regional monitoring and management. FAO Fisheries and Aquaculture Technical Paper No. 600. Rome.

Giordano, S., J. Lazar, D. Bruce, C. Little, D. Levin, H.W. Slacum Jr., J. Dew-Baxter, L. Methratta, D. Wong, and R. Corbin. 2010. Quantifying the effects of derelict fishing gear in the Maryland portion of Chesapeake Bay. In: Final Report to the NOAA Marine Debris Program. National Oceanic and Atmospheric Administration, Silver Spring, Maryland.

Glaspie, C.N., K. Longmire, and R.D. Seitz. 2017. Acidification alters predator-prey interactions of blue crab Callinectes sapidus and soft-shell clam Mya arenaria. Journal of Experimental Marine Biology and Ecology 489: 58-65.

Guillory, V. 1993. Ghost fishing by blue crab traps. North American Journal of Fisheries Management 13: 459-466. 
Guillory, V., A. McMillen-Jackson, L. Hartman, H. Perry, T. Floyd, T. Wagner, and G. Graham. 2001. Blue crab derelict traps and trap removal programs. Gulf States Marine Fisheries Commission, Ocean Springs, Mississippi.

Havens, K.J., D.M. Bilkovic, D. Stanhope, K. Angstadt, and C. Hershner. 2008. The effects of derelict blue crab traps on marine organisms in the Lower York River, Virginia. North American Journal of Fisheries Management 28(4): 1194-1200. DOI: 10.1577/M07-014.1

Havens, K.J., D.M. Bilkovic, D. Stanhope, and K. Angstadt. 2011. Fishery failure, unemployed commercial fishers, and lost blue crab pots: An unexpected success story. Environmental Science and Policy 14: 445-450.

Hines, A.H., A.M. Haddon, and L.A. Wiechert. 1990. Guild structure and foraging impact of blue crabs and epibenthic fish in a subestuary of Chesapeake Bay. Marine Ecology Progress Series 67: 105-126.

Hines, A.H. 2007. Ecology of juvenile and adult blue crabs. Pages 565-630 in V. Kennedy and E. Cronin, editors. The blue crab: Callinectes sapidus. Maryland Sea Grant, College Park.

Hines, A.H., W.C. Long, J.R. Terwin, and S.F. Thrush. 2009. Facilitation, interference, and scale: the spatial distribution of prey patches affects predation rates in an estuarine benthic community. Marine Ecology Progress Series 385:127-135.

Kennedy, V.S., M. Oesterling, and W.A. Van Engel. 2007. History of blue crab fisheries on the U.S. Atlantic and Gulf coasts. Pages 655-709 in V. Kennedy and L. Cronin (eds) The Blue crab: Callinectes sapidus. Maryland Sea Grant College, College Park.

Macfadyen, G., T. Huntington, and R. Cappell. 2009. Abandoned, lost or otherwise discarded fishing gear (No. 523). Food and Agriculture Organization of the United Nations (FAO). Rome, Italy.

Matsuoka, T., T. Nakashima, and N. Nagasawa. 2005. A review of ghost fishing: scientific approaches to evaluation and solutions. Fisheries Science 71: 691-702.

Micheli, F. and C.H. Peterson. 1999. Estuarine vegetated habitats as corridors for predator movements. Conservation Biology 13(4): 869-881.

Miller, T.J., M.J. Wilberg, A.R. Colton, G.R. Davis, A. Sharov, R.N. Lipcius, G.M. Ralph, E.G. Johnson, and A.G. Kaufman. 2011. Stock Assessment of Blue Crab in Chesapeake Bay 2011: Final Assessment Report. Ref: [UMCES] CBL 11-011. UMCES Tech. Ser. No. TS-614-11-CBL.

National Marine Fisheries Service. 2017. Fisheries Economics of the United States, 2015. U.S. Dept. of Commerce, NOAA Tech. Memo. NMFS-F/SPO-170, 247p. 
R Core Team. 2018. R: A language and environment for statistical computing. R Foundation for Statistical Computing, Vienna, Austria. URL https://www.R-project.org/.

Scheld, A.M., D.M. Bilkovic, and K.J. Havens. 2016. The dilemma of derelict gear. Scientific Reports 6: 19671.

Seitz, R.D., K.E. Knick, and M. Westphal. 2011. Diet selectivity of juvenile blue crabs (Callinectes sapidus) in Chesapeake Bay. Integrative and Comparative Biology 51(4): 598-607.

Stover, K.K., K.G. Burnett, E.J. McElroy, and L.E. Burnett. 2013. Locomotory fatigue during moderate and severe hypoxia and hypercapnia in the Atlantic Blue Crab, Callinectes sapidus. The Biological Bulletin 224(2): 68-78.

Uhrin, A.V., M.S. Fonseca, and G.P. DiDomenico. 2005. Effect of Caribbean Spiny Lobster Traps on Seagrass Beds of the Florida Keys National Marine Sanctuary: Damage Assessment and Evaluation of Recovery. American Fisheries Society Symposium 41: 579-588.

Uhrin, A.V. and J. Schellinger. 2011. Marine debris impacts to a tidal fringing-marsh in North Carolina. Marine Pollution Bulletin 62(12): 2605-2610.

Van Engel, W.A. 1958. The blue crab and its fishery in Chesapeake Bay: Part I. Reproduction, early development, growth and migration. Commercial Fisheries Review 20(6): 6-17.

Virnstein, R.W. 1977. The importance of predation by crabs and fishes on benthic infauna in Chesapeake Bay. Ecology 58: 1200-1217.

Voss, C.M., J.A. Browder, A. Wood, and A. Michaelis. 2015. Factors driving the density of derelict crab pots and their associated bycatch in North Carolina waters. Fishery Bulletin 113(4): 378-390.

Wilcox, C., N.J. Mallos, G.H. Leonard, A. Rodriguez, and B.D. Hardesty. 2016. Using expert elicitation to estimate the impacts of plastic pollution on marine wildlife. Marine Policy 65: 107-114.

Williams, A.B. 1974. The swimming crabs of the genus Callinectes (Decapoda: Portunidae). Fishery Bulletin 72(3): 685-798.

Wolcott, T.G. and A.H. Hines. 1990. Ultrasonic telemetry of small-scale movements and microhabitat selection by molting blue crabs (Callinectes sapidus). Bulletin of Marine Science 46(1): 83-94. 
Figures and Tables

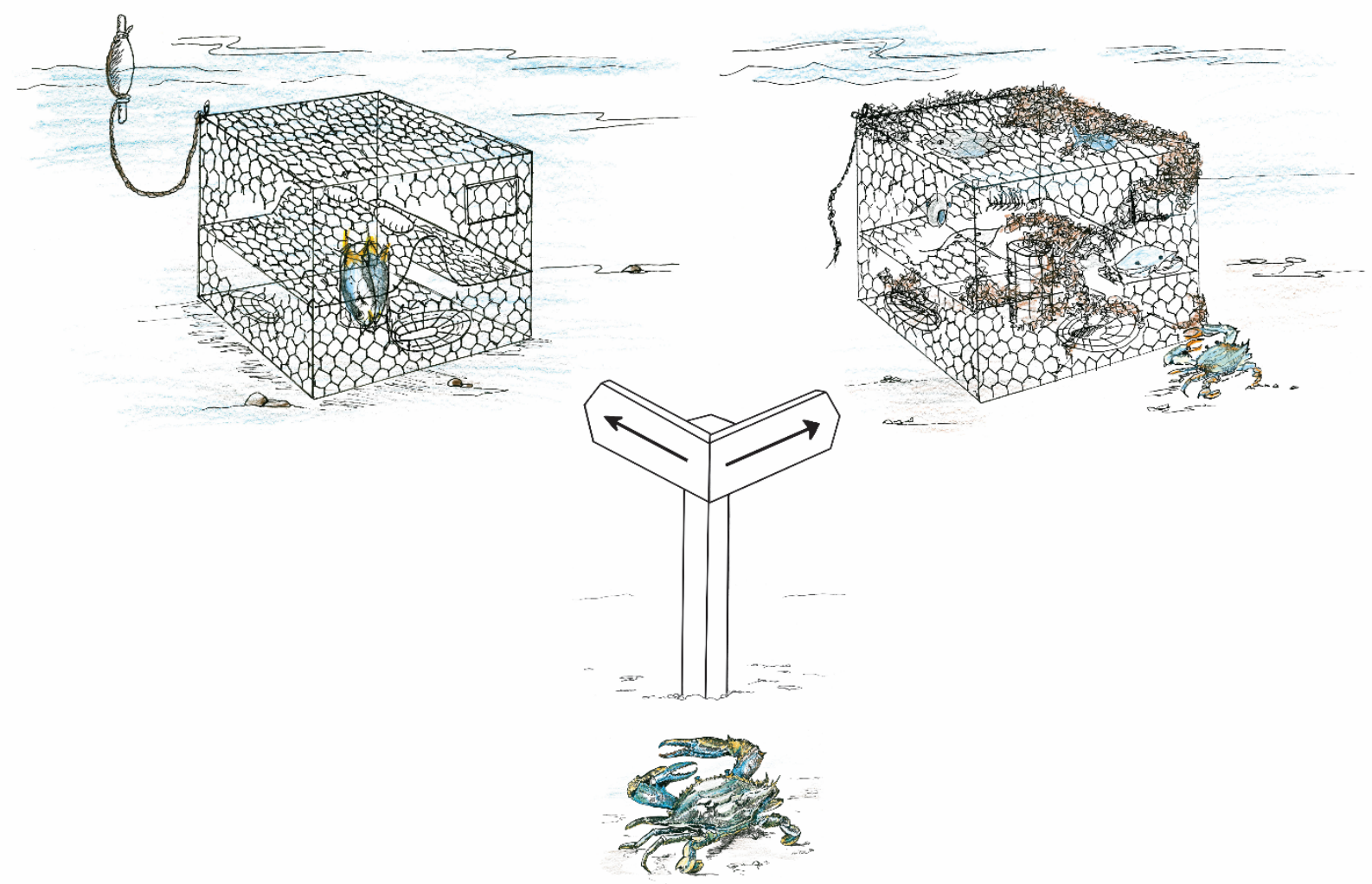

Figure 1. Illustration of the competition effect between actively fished (left) and derelict (right) pots. Commercial fishers regularly bait the active pots to attract blue crabs, but nearby derelict pots may attract crabs away from the active pots. Whether or not the blue crab enters the derelict pot, it will be removed from the commercial fisher's harvest. 


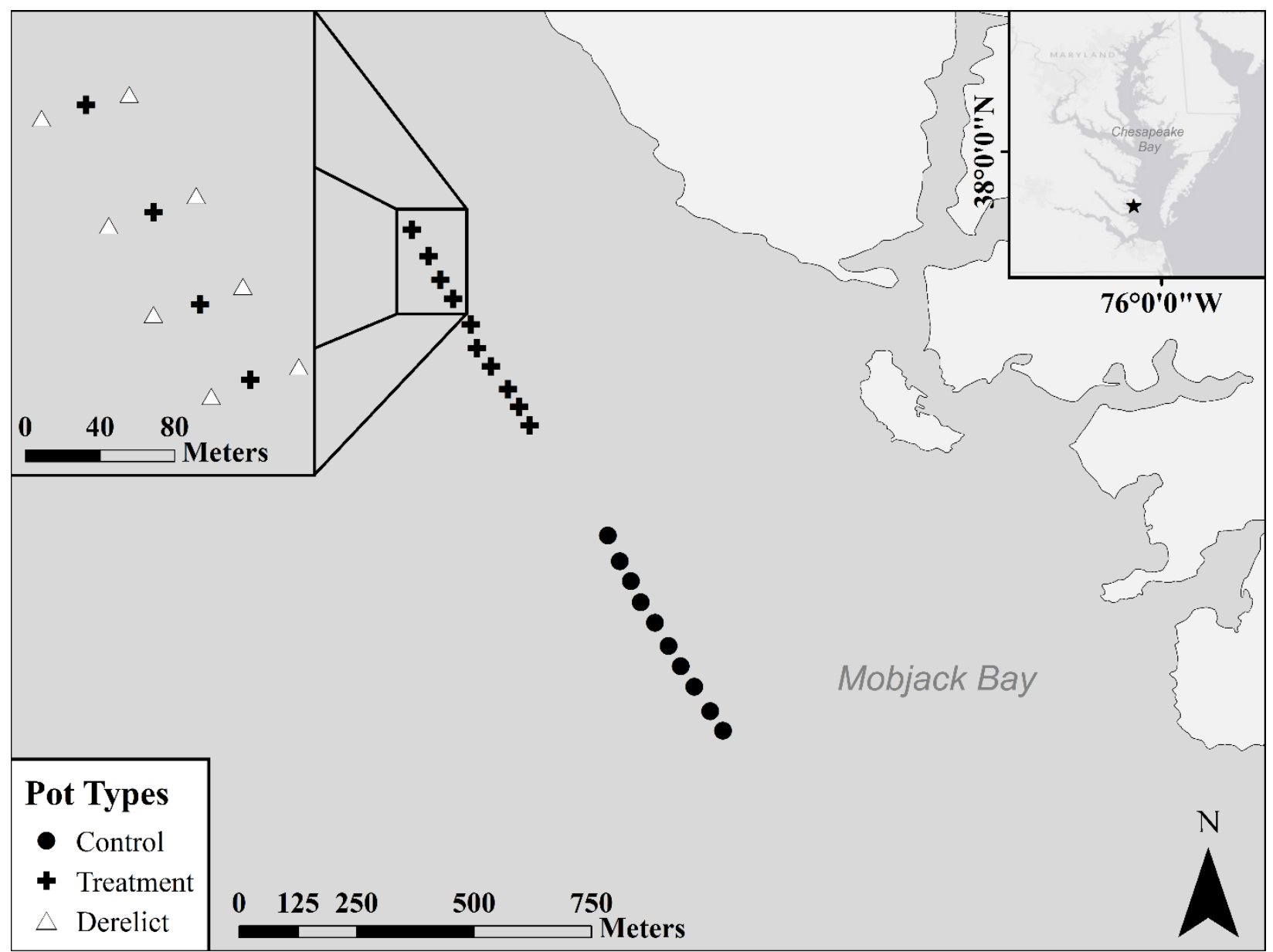

Figure 2. Diagram of the experimental design at the study site in Mobjack Bay, Virginia. 


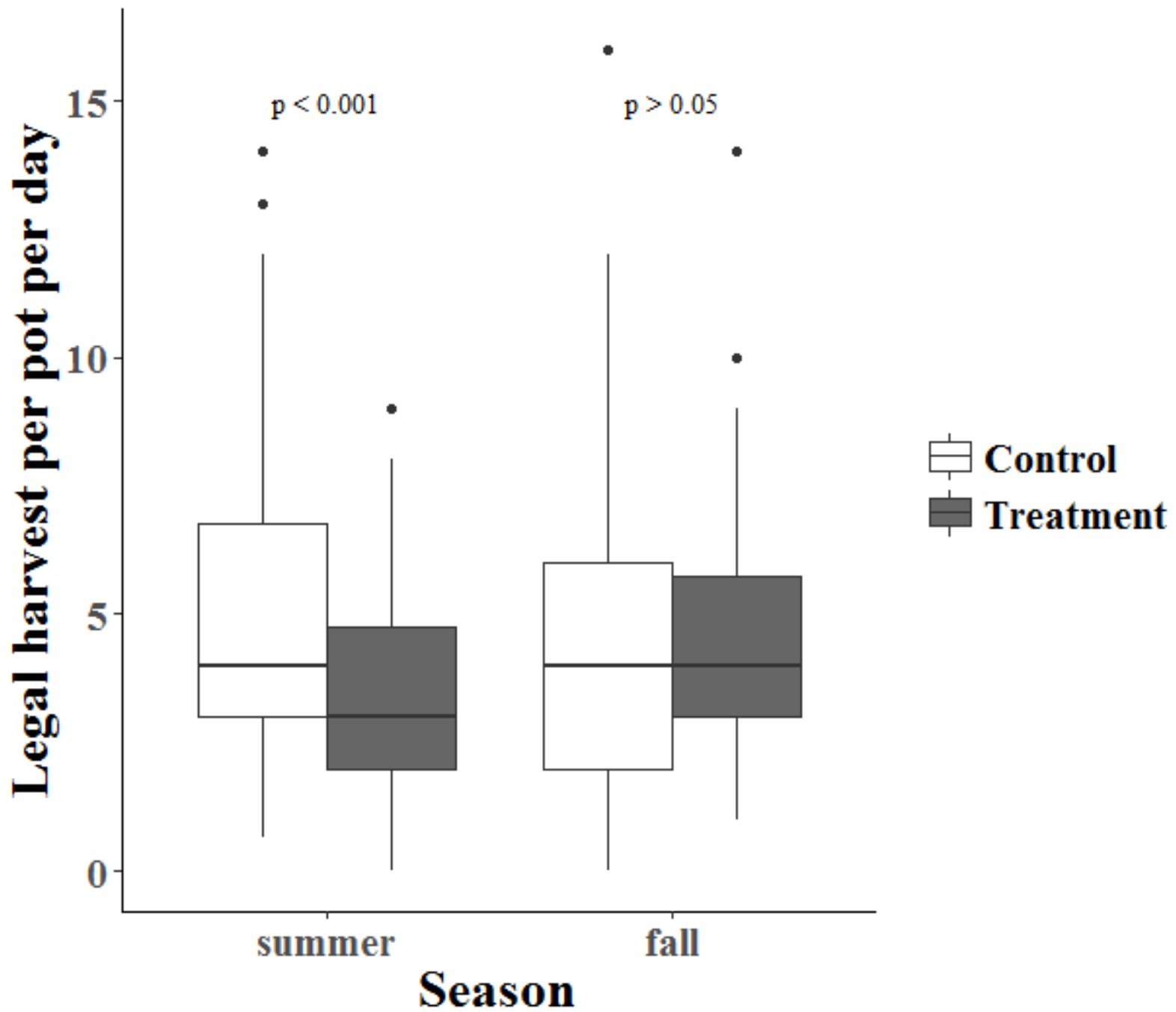

Figure 3. Boxplots of blue crab legal harvest rates (crabs/pot/day) for active pots by experimental group (Control or Treatment) during each season (summer or fall). 
Table 1. Rates of blue crabs per pot per day recorded during the different seasons and within each type of active pot (Control = active pot within control group, Treatment $=$ active pot within treatment group). Statistical results from Mann-Whitney U tests comparing corresponding control/treatment pot types within the same season are represented by the $\mathrm{U}$ statistic and significance $(* \mathrm{p}<0.05$, $* * \mathrm{p}$ $\leq 0.01, * * * \mathrm{p}<0.001)$.

\begin{tabular}{|c|c|c|c|c|c|c|c|c|c|c|c|c|}
\hline \multirow[t]{2}{*}{ Season } & \multirow[t]{2}{*}{ Pot Type } & \multicolumn{4}{|c|}{ Legal Harvest Rate } & \multicolumn{3}{|c|}{ Sublegal Catch Rate } & \multicolumn{4}{|c|}{ Total Catch Rate } \\
\hline & & Mean [SE] & Median & $U$ & & Mean [SE] & Median & $U$ & Mean [SE] & Median & $U$ & \\
\hline \multirow{2}{*}{ Summer } & Control $(\mathrm{n}=110)$ & $4.98[0.27]$ & 4.00 & & & $0.89[0.09]$ & 0.83 & & $5.87[0.30]$ & 5.00 & & \\
\hline & Treatment $(\mathrm{n}=110)$ & $3.29[0.19]$ & 3.00 & $8,280.5$ & $* * *$ & $0.72[0.08]$ & 0.50 & $6,585.0$ & $4.01[0.21]$ & 4.00 & $8,205.5$ & $* * *$ \\
\hline \multirow{2}{*}{ Fall } & Control $(n=110)$ & $4.60[0.28]$ & 4.00 & & & $1.35[0.11]$ & 1.00 & & $5.95[0.30]$ & 5.50 & & \\
\hline & Treatment $(\mathrm{n}=110)$ & $4.37[0.23]$ & 4.00 & $6,166.0$ & & $1.15[0.09]$ & 1.00 & $6,611.0$ & $5.52[0.24]$ & 5.00 & $6,499.5$ & \\
\hline
\end{tabular}


Table 2. Rates of blue crabs per pot per day by sex recorded during the different seasons and within each experimental group (Control = active pot within control group, Treatment = active pot within treatment group). Statistical results from Mann-Whitney U tests comparing corresponding sex control/treatment pot types within the same season are represented by the U statistic and significance (* $\underline{\mathrm{p}<0.05, * * \mathrm{p}<0.01, * * * \mathrm{p}<0.001)}$.

\begin{tabular}{|c|c|c|c|c|c|c|c|c|c|c|c|c|c|c|}
\hline \multirow[t]{2}{*}{ Season } & \multirow[t]{2}{*}{ Pot Type } & \multirow[t]{2}{*}{ Sex } & \multicolumn{4}{|c|}{ Legal Harvest Rate } & \multicolumn{4}{|c|}{ Sublegal Catch Rate } & \multicolumn{4}{|c|}{ Total Catch Rate } \\
\hline & & & Mean [SE] & Median & $U$ & & Mean [SE] & Median & $U$ & & Mean [SE] & Median & $U$ & \\
\hline \multirow{4}{*}{ Summer } & \multirow{2}{*}{ Control $(n=110)$} & Male & $1.01[0.01]$ & 1.00 & & & $0.37[0.05]$ & 0.00 & & & $1.37[0.12]$ & 1.00 & & \\
\hline & & Female & $3.97[0.24]$ & 3.00 & & & $0.53[0.08]$ & 0.00 & & & $4.50[0.27]$ & 4.00 & & \\
\hline & \multirow{2}{*}{ Treatment $(\mathrm{n}=110)$} & Male & $0.91[0.09]$ & 1.00 & $6,426.5$ & & $0.42[0.07]$ & 0.00 & $5,959.5$ & & $1.34[0.11]$ & 1.00 & $6,186.0$ & \\
\hline & & Female & $2.38[0.16]$ & 2.00 & $8,343.0$ & $* * *$ & $0.29[0.04]$ & 0.00 & $6,696.5$ & & $2.67[0.17]$ & 2.50 & $8,456.5$ & $* * *$ \\
\hline \multirow{4}{*}{ Fall } & \multirow{2}{*}{ Control $(\mathrm{n}=110)$} & Male & $0.48[0.07]$ & 0.00 & & & $0.53[0.07]$ & 0.00 & & & $1.01[0.10]$ & 1.00 & & \\
\hline & & Female & $4.12[0.26]$ & 4.00 & & & $0.82[0.10]$ & 1.00 & & & $4.94[0.28]$ & 5.00 & & \\
\hline & \multirow{2}{*}{ Treatment $(n=110)$} & Male & $0.76[0.08]$ & 1.00 & $4,817.0$ & $* *$ & $0.70[0.07]$ & 1.00 & $5,207.0$ & * & $1.46[0.10]$ & 1.00 & $4,460.0$ & $* * *$ \\
\hline & & Female & $3.61[0.23]$ & 3.00 & $6,680.5$ & & $0.45[0.07]$ & 0.00 & $7,432.5$ & $* *$ & $4.06[0.24]$ & 4.00 & $7,086.0$ & * \\
\hline
\end{tabular}


Table 3. Results of the negative binomial mixed model bootstrap estimates for legal-size blue crab harvest in active pots (number of observations $=440$; residual $\mathrm{df}=433$; Significance: ${ }^{*} \mathrm{p}<$ $0.05, * * \mathrm{p}<0.01, * * * \mathrm{p}<0.001)$.

\begin{tabular}{|c|c|c|c|}
\hline Predictor Variables & Coefficient & SE & Sig. \\
\hline Intercept & 1.731 & 0.083 & *** \\
\hline Season & 0.242 & 0.064 & *** \\
\hline Treatment & 0.421 & 0.099 & *** \\
\hline Soak time & +0.052 & 0.033 & \\
\hline Season:Treatment & $\begin{array}{l}+\quad 0.390 \\
\end{array}$ & 0.092 & $* * *$ \\
\hline
\end{tabular}

